\title{
Spatial Planning and its need for national and regional bibliographies of grey literature
}

This is an Accepted Manuscript of an article published by Taylor \& Francis in Cataloging \& Classification Quarterly on 04 March 2019, available at

http://www.tandfonline.com/10.1080/01639374.2019.1570993

Christian Erlinger

Vienna Public Libraries, Austria

christian.erlinger-schiedlbauer@wien.gv.at

(iD) https://orcid.org/0000-0001-7872-9617 


\section{Abstract}

National bibliographies grant an interesting potential to search for new publications in specific scientific disciplines. This article gives an overview about the bibliographic potential of National Bibliographies in the German-speaking countries for spatial planning both in research and practice. Due to the circumstance that grey literature plays an important role in technical disciplines, a national bibliography is a worthwhile source for information retrieval. This article presents furthermore a light-weight python-script to parse the bibliographic information from spatial planning relevant literature and to measure the importance of grey literature using the SRU-API of the German National Library.

\section{Introduction}

Academic research in spatial planning uses a wide range of different methods. Especially the research focused on practical planning is often based on field research, but needs to be underlaid with literature about thoughts and meanings as it is scientifically common. Furthermore the planning practice is legally bound to create previously a so-called 'basic research'. Such a research assumes primarily the ideas and targets of earlier planning concepts in the specific spatial area. Both academic research and practice depend on an appropriate literature support for their work. Especially grey literature plays an important role. Studies, manifestos, concepts, plans and other different documents from public authorities are widely used in the spatial disciplines. Structured bibliographies with a detailed geographically enriched metadata could be worth the effort to become an useful datasource for spatial researchers. On the one hand to have the possibility to get an overview about newest publications in the whole discipline or in specific geographic or 
thematic context and on the other hand to have a very sophisticated tool for scientific information retrieval.

This article will give an impression of the current situation of spatial planning relevant documents covered through national bibliographies in the German speaking countries. The three national libraries of Germany, Austria and Switzerland have implemented different strategies to archive and describe the collected documents. An important focus of this article is the cataloging of grey literature, especially grey literature which is only available online. That means that libraries' strategies for web-harvesting and methods to create structured metadata about the geographical or thematic coverage will become more and more important for subject-based research. This article discusses fast and light-weight possibilities to harvest metadata from national bibliographies in an automatic way for presentation or analyzing. Therefore, the technical availability plays an import role. National bibliographies could not be any more than just a printed list of the last publications received by a national library, but the bibliographic metadata have to be searchable in all its details, accessible as easily as possible for both human and machine.

\section{Information usage and production in spatial planning research}

The aim of spatial planning is to manage and influence the human use of the landscape. Research on spatial planning is responsible to create and reflect theories and methods for developing new systems of planning the development of the human used space. Whatever a landscape will be used by humans, for traffic, industry, housing, recreation, agriculture or even as a rural body, spatial planning is highly important to create a sustainable ecosystem in respect of all the existing different and contradictory interests. 
'It can be more or less associated with government, with local governance, with scientific expertise, with planners and plans. It can be procedural or content-driven and dominated by political, economic, or legal actors in various combinations. In addition, it can codify a future spatial organization to different degrees and by different means.'

Both spatial planning research and practice are designing plans and interact with the community. Before spatial plans will be implemented in the real world, all the plans, its ideas and meanings are documents. Such 'documents' produced through spatial science or practice are based on text and illustrated through maps, charts, images and display in each way a spatial 'meaning' and shall be part of a spatial and social discourse. ${ }^{2}$

Furthermore spatial planning relevant documents have some dialectic between legally bound documents (so-called 'formal' documents) and not legally bound ('informal') ${ }^{3}$ :

Legally bound documents based on structured processes and actions defined by law. ${ }^{4}$ To this document group we can count the land-use plan or the development plan, if there exists a local law which describes the process of creation and its effect.

Not legally bound documents could be described as the rest of all existing planning documents without any legal obligation. The spatial planners of the future are more and more obligated 'to prepare guidance documents which can be used in

\footnotetext{
Kristof Van Assche et al., "Co-Evolutions of Planning and Design: Risks and Benefits of Design Perspectives in Planning Systems", Planning Theory 12, no. 2 (May 2013): 178, doi:10.1177/1473095212456771.

2 Michael K. Buckland, "Information as Thing", Journal of the American Society of Information Science 42, no. 5 (June 1991): 355.

3 Kaliopa Dimitrovska Andrews, "Mastering the City: Formal and Informal Planning Tool"', Urbani Izziv 9 , no. 2 (1998): 115.

4 Peter Runkel, "Fachplanungen", in Handwörterbuch Der Raumordnung (Hannover: Verlag der ARL, 2005), 281.
} 
negotiating the convergence between interested parties ${ }^{, 5}$. Therefore the amount of informal documents is not only 'the rest' of the planning documents, it is especially for the planning research the base of all developments. These planning documents are flexible in content and design and allow the planners to react immediately under consideration of the different interests and perspectives in the given situations. ${ }^{6}$ Nowadays there is no spatial relevant project without any type of master-plan, strategic analysis or conceptual study.

All the planning relevant documents both formal and informal (legally and not legally bound) are often funded by governmental authorities and created by planners, researchers or public servants. A great number of the created documents will be published online. Based on national laws, legally obligated documents funded or edited by public authorities have to be published or accessible in a public or open way. ${ }^{7}$ Not legally bound planning documents which were published online only are missing bibliographic sustainability. Online publications from public authorities or planning agencies are missing any stable links and will often not be archived in any institution, whether in libraries or in an institutional archive. Not legally bound documents could be grey literature or published over traditional channels, nonetheless these documents build the pool of ideas and strategies to create new spatial developments or to make critical research on it.

For a new research or planning activity it is necessary to get an overview of existing spatial ideas, according to the planning area or as references to proposed implementation.

5 Kaliopa Dimitrovska Andrews, "Mastering the City: Formal and Informal Planning Tool", Urbani Izziv 9, no. 2 (1998): 115.

6 Rainer Danielzyk, "Informelle Planung”, in Handwörterbuch Der Raumordnung (Hannover: Verlag der ARL, 2005), 465.

7 "Directive 2003/98/EC of the European Parliament and of the Council of 17 November 2003 on the Re-Use of Public Sector Information", EUR-Lex - 32003L0098 - EN § (n.d.), https://eur-lex.europa.eu/legal-content/EN/ALL/?uri=CELEX:32003L0098 (accessed January 9, 2019). 
'It is not possible to get an exact overview of the number, the form, the validity, or the accessibility of information relevant for spatial planning. It is the question, which spatial relevant information are accessible at all?'8

Planning practice and research are aware of this problem about information access as mentioned in the cited thesis before. Information specialists or librarians should be able to handle this information gap to give attention to the following aspects or needs:

Create and store bibliographic metadata necessary both for research and practice in a standardized and known way, for easy and stable reuse and discovery.

Design possibilities for special information retrieval or information needs in the served discipline. E.g. spatial research needs a high quality of geographic information given in the metadata. The usage of controlled geographic authority files enable the possibility to create a spatial index and to build a map-based discovery tool.

\section{Importance of grey literature in spatial planning}

One of the most common and known definitions of grey literature is the so-called Luxemburg definition, which was approved on Third International Conference on Grey Literature in 1997:

'[Grey Literature] is produced on all levels of government, academics, business and industry in print and electronic formats, but which is not controlled by commercial publishers."

8 Jürgen Hayer, “Überörtliches Planungsinformationssystem Für Österreich" (Master thesis, TU Wien, 2012), 15.

9 Joachim Schöpfel and Dominic J. Farace, "Grey Literature", in Encyclopedia of Library and Information Sciences, 2009, 2029, 10.1081/E-ELIS3-120043732. 
In 2011 new attributes were added to the definition which was subsequently proposed as the Prague definition:

'Grey literature stands for manifold document types produced on all levels of government, academics, business and industry in print and electronic formats that are protected by intellectual property rights, of sufficient quality to be collected and preserved by library holdings or institutional repositories, but not controlled by commercial publishers i.e., where publishing is not the primary activity of the producing body. ${ }^{, 10}$

An interesting further attribute on grey literature which could be added is the fact, "that many forms of grey literature, such as government documents and working papers, have a history of being open available, even long before the current open access movement. ${ }^{, 11}$

The importance of grey literature in distributing, scientific, technical or general information were mentioned in its detailed depth as it is given in academic publication types like theses, working papers or conference proceedings and through the fact, that publishing information outside commercial publishing routines is quite faster. But the most important fact of the importance of grey literature is that the published informations 'simply are not published elsewhere.' 12

Spatial Planning relevant documents are rarely published through the commercial publishing and distribution channel. As mentioned in the chapter before, planning documents are created through public authorities, researchers or planners and often

10 Joachim Schöpfel, "Towards a Prague Definition of Grey Literature: Transparency in Grey Literature.", in Grey Tech Approaches to High Tech Issues (Twelfth International Conference on Grey Literature, Prague, 2010), 11-26, https://archivesic.ccsd.cnrs.fr/sic_00581570/ (accessed January 9, 2019).

11 Wanda R Marsolek et al., "The Types, Frequencies, and Findability of Disciplinary Grey Literature within Prominent Subject Databases and Academic Institutional Repositories", Journal of Librarianship and Scholarly Communication 6, no. 1 (30 April 2018): 3, doi:10.7710/2162-3309.2200.

12 Schöpfel and Farace, "Grey Literature", 2031. 
funded through governmental institutions or activities. Also the free and open online accessibility of planning documents covers the definition of grey literature.

In the following chapters of this article and its analysis we want to attempt the relative occurrence of spatial planning relevant literature covered in national bibliographies.

\section{Spatial planning relevant content covered in National Bibliographies}

The lack of a centralized archiving of bibliographic information of grey literature in spatial planning in form of a commercial specialized database leads to the idea to build an institutional or disciplinary repository including a focus on the spatial disciplines. ${ }^{13}$ But it is also interesting to know in which way existing national bibliographies are in the state to cover specific needs for such specific information or to become an essential data-hub for building a specialized repository.

'A current national bibliography is a mirror that reflects the culture of a country. [...] The emphasis on agriculture and technology, the make-up of its society through its various language publications [...] are all discernible. A current national bibliography should reflect the interests and unique characteristics of a country much as a mirror reflects the uniqueness of an individual. ${ }^{14}$

Under Barbara L. Bell's point of view cited above a national bibliography could be established as a central hub for well cataloged metadata of different types of publications with impact on spatial planning research and practice, even this output has the appropriate

13 Christian Erlinger and Uroš Miloradović, "Vorhabensstudie für ein Fachrepositorium Raumplanung an der TU Wien", 2016, http://resolver.obvsg.at/urn:nbn:at:at-ubtuw:3-2065 (accessed January, 14 2019).

14 Barbara L. Bell, An Annotated Guide to Current National Bibliographies, 2nd completely rev. ed, UBCIM Publications, new ser., v. 18 (München: K.G. Saur, 1998). 
geographical coverage or national importance. The three main objectives of a national bibliography are

- Assistance for cataloging in libraries

- Assistance in selection and acquisition

- Base for further information searching, retrieval and document supply ${ }^{15}$

Creating a national bibliography as a central and sophisticated information resource has to be seen as a base for different searching tools and has to be accessible on many points and in different ways. The linking to local catalogs in libraries and similar institutions and vice versa is also necessary to increase the importance of a national bibliography as the enabling or at least documenting of the full-text access to different publications.

\section{National bibliographies and grey literature}

National bibliographies covers the literature produced in or about a defined geographical area. In the German speaking countries there are the 'Deutsche Nationabibliografie' for Germany, the 'Österreichische Bibliografie' for Austria and 'Das Schweizer Buch' for Switzerland. Grey literature is documented separately in the German national bibliography in the so-called 'Reihe B' (publications outside publishing and book-trade market). The German national bibliography generally knows different parts. Relevant for this article are the 'Reihe A', which describes the new publications of the traditional publishing and distributions channels, 'Reihe B' covers, as mentioned before, grey literature, 'Reihe H' dissertations and 'Reihe O' online publications. The Austrian and Swiss national bibliographies have no separate bibliography for grey literature or thesis and dissertations.

15 Maja Žumer, National Bibliographies in the Digital Age : Guidance and New Directions, Final Draft, 2008, 6, http://archive.ifla.org/VII/s12/guidelines-national-bibliographies-electronic-age.pdf (accessed January 9, 2019). 
The coverage of the national bibliographies is often restricted to forms and (media) types of the different publications. Although the IFLA recommendations on national bibliographies (1998) mention, that 'all documents published in a country regardless of publication form - they could be printed, be audio-visual or electronic documents - should be covered by the national bibliographic registration, ${ }^{16}$, especially online published grey literature is rarely cataloged in national bibliographies.

\section{National bibliographies and online publications}

A further aspect of spatial relevant information is the fact, that an increasingly high number of this literature is accessible exclusively online.

'Electronic resources are just one of many formats that a national bibliographic agency collects in support of providing its users with a full range of content that emanates from the home country; ${ }^{17}$

The German National bibliography with the so-called 'Reihe O' has an independent bibliography for online published publications. All registered documents are in its form orientated at classical print-publications, that means that records in bibliography of 'Reihe O' are more about pdf-files, which are strictly oriented on traditional printed documents, and less about web-oriented publications. Literature cataloged in 'Reihe $\mathrm{O}$ ' is mainly delivered through the publishers itself, due to the legal obligation for delivering publications to the National Library. ${ }^{18}$

16 Randi Diget Hansen, "History and Background", in Žumer, Maja (Ed.). National Bibliographies in the Digital Age : Guidance and New Directions, 2008, 13, http://archive.ifla.org/VII/s12/guidelines-national-bibliographies-electronic-age.pdf (accessed January 9, 2019).

17 Beacher Wiggins, "Selection Principles", in Žumer, Maja (Ed.). National Bibliographies in the Digital Age : Guidance and New Directions, 2008, 15, http://archive.ifla.org/VII/s12/guidelines-national-bibliographies-electronic-age.pdf.

18 "Deutsche Nationalbibliografie, Reihe O 'Online-Publikationen'”, 2016, http://www.dnb.de/DE/Service/DigitaleDienste/DNBBibliografie/reiheO.html (accessed January 9, 2019). 
Unfortunately it has to be assumed that a significant number of relevant documents for spatial planning will not be delivered to a national or regional library by their creators or publishers. Project-based or institutional websites offer different types of documents and medias which could become important for future spatial development or research. That is one of the common reasons why web-archiving became an interesting field of activity for libraries. The Web 'has increasingly evolved into a storehouse of valuable scientific, cultural and historical information. ${ }^{19}$ The German National Library started their initiative for web-archiving in 2013. About 700 websites from public authorities or cultural institutions had been archived initially. ${ }^{20}$ Uncertainties due to copyright-law prevent the National Library to start a wider web-crawl and to make this web-archive public accessible. ${ }^{21}$

The Austrian National Library is also running a web-archive to harvest websites with a at top-level domain or websites with an social, cultural or economic importance for Austria. Access to the archive is, due to copyright-law, also limited to terminals in the Austrian National Library. ${ }^{22}$ The Austrian National Library is also obligated to collect online publications like e-books, electronic theses etc., as they are collected and cataloged in the German 'Reihe O'. The Austrian national bibliography certainly has no separate part for online publications.

The Swiss National Library runs with e-Helvetica a national initiative to collect online publications and websites from Switzerland or with an appropriate importance for the Swiss cultural and social heritage. ${ }^{23}$

19 Kahle Brewster, "Preserving the Internet", Scientific American 276, no. 3 (1997): 82-83.

20 Tobias Beinert, Ulrich Hagenah, and Anna Kugler, "Es war einmal eine Website... - Kooperative Webarchivierung in der Praxis", o-bib. Das offene Bibliotheksjournal / herausgegeben vom VDB, Bd. 1, Nr. 1 (2014), 19 December 2014, 293, doi:10.5282/o-bib/2014h1s291-304.

21 Brewster, 'Preserving the Internet', 294-95.

22 https://webarchiv.onb.ac.at/ (accessed January 9, 2019).

23 Balzardi, "Das Projekt E-Helvetica Der Schweizerischen Nationalbibliothek", 2006, https://www.nb.admin.ch/dam/snl/de/dokumente/e-helvetica/publikationen/balzardi_elena_dasprojekte-h 


\section{Information retrieval in national bibliographies}

The information retrieval in national bibliographies is the central question, whether national bibliographies have an importance for research or practice.

'[The] national bibliography is an important information resource for various user groups in different contexts [...]. The interface should, as much as possible, enable all the functionality needed by these user groups. [...] Therefore the interface has to be simple, clear and tolerant to mistakes. ${ }^{24}$

Different user groups have different needs and requirements for searching information based on national bibliographies. For users related to spatial sciences the following criteria according to Žumer should be achieved through the bibliography: ${ }^{25}$

\section{Metadata Criteria - stored, searchable and displayed:}

- Title, author, editor

- Publication year

- Geographical coverage

- Legal validity concerning its geographically or chronologically impact

- Subject headings, classification and keywords, especially based on professional thesauri or authority data commonly used in planning practice. (e.g. regional identifier for geographical or administrative entities)

\section{For the re-use of records}

- Common identifier for the metadata-record

- Permanent identifier for stable referencing

- Legal information about the accessibility and copyright

elveticaderschweizerischennationalbi.pdf.download.pdf/balzardi_elena_dasprojekte-helveticaderschweiz erischennationalbi.pdf (accessed January 9, 2019).

24 National Bibliographies in the Digital Age : Guidance and New Directions, 35.

25 Ibid., 9-12. 
- Technical possibility to search or collect data via standardized interfaces like SRU, OAI-PMH or Z39.50

In the German speaking countries the most common form of presentation of the national bibliography seems to be a pdf-file, a digitized printable or printed list of publications ${ }^{26}$. These documents are structured in a chronically order within a publication interval of one (Germany) or two weeks (Austria, Switzerland). The cataloged publications are classified in all three national bibliographies by a subset of about 100 top-level items of the Dewey Decimal Classification (DDC). ${ }^{27}$ This form of presentation could be classified as simple but it misses any type of an interactive user-interface. Only the German National Library allows to parse the national bibliography through the standardized protocols OAI-PMH and SRU. This allows a deeper, better focused and individual, subject-based research as well as to re-use the data in a new context. To search for spatial planning relevant publications there exist different possibilities, in this article the following two methods are chosen:

Spatial planning is classified in DDC in 710.

Search for different specialized keywords like Stadt*, Raum*, Region*

\section{Spatial planning relevant documents in German national bibliography retrieved by DDC}

To get an overview of the number of cataloged records relevant to spatial planning, we have developed a light-weight python script, which uses the SRU-Protocol at the German National Library. ${ }^{28}$ The script produces a list with the number of records and creates a bar

26 German National Library: http://d-nb.info/998466212 (accessed January 9, 2019); Austrian National Library: https://www.onb.ac.at/digitale-bibliothek-kataloge/oesterreichische-bibliografie/neuerscheinungen-2018/ (accessed January 9, 2019); Swiss National Library: http://ead.nb.admin.ch/web/sb-pdf/ (accessed January 9, 2019).

27 http://www.dnb.de/DE/Erwerbung/Inhaltserschliessung/sachgruppenDnb.html (accessed January 9 , 2019).

28 http://services.dnb.de/sru/dnb?version=1.1 (accessed January 9, 2019). 
chart to visualize the development of the number of documents in a specific time period.

Itis freely available for re-use and validation on GitHub as a Jupyter Notebook with further information and comments. ${ }^{29}$

The script was used three times to parse three different parts of the German national bibliography. Additional to 'Reihe B' ( cataloging grey literature) and 'Reihe O' (online publications) we also parsed the 'Reihe H' (dissertations). The 'Reihe H' lost its importance in the last years, because an increasing number of theses were published online on institutional repositories, so publications formerly cataloged in 'Reihe $\mathrm{H}$ ' have moved to 'Reihe O'. The chosen time period is given to the fact, that in 2010 cataloging of 'Reihe O' was established.

\begin{tabular}{|c|c|c|c|c|c|c|c|c|c|}
\hline & 2010 & 2011 & 2012 & 2013 & 2014 & 2015 & 2016 & 2017 & Aver. \\
\hline Reihe A & 225 & 193 & 202 & 270 & 281 & 217 & 190 & 187 & 221 \\
\hline Reihe B & 172 & 117 & 115 & 77 & 135 & 176 & 109 & 121 & 128 \\
\hline Reihe H & 23 & 17 & 28 & 22 & 42 & 24 & 11 & 8 & 22 \\
\hline Reihe $\mathbf{O}$ & 727 & 367 & 425 & 493 & 509 & 607 & 872 & 528 & 566 \\
\hline $\operatorname{Sum}(B+H)$ & 195 & 134 & 143 & 99 & 177 & 200 & 120 & 129 & 150 \\
\hline $\begin{array}{l}\text { Rel. } \\
(B+H) / A\end{array}$ & 0,87 & 0,69 & 0,71 & 0,37 & 0,63 & 0,92 & 0,63 & 0,69 & 0,69 \\
\hline
\end{tabular}

Tab. 1 Number of Records in German national bibliography for DDC 710.

The numbers in Tab. 1 and Figure 1 show the importance of grey literature ('Reihe B') and even more of online publications ('Reihe O') in context of spatial planning compared to

29 https://github.com/LibrErli/DNB_for_Spatial-Planning (accessed January 9, 2019). 
literature published through the traditional channels of distribution and publishing cataloged in 'Reihe A'. We can also observe an increasing number of cataloged online publications, although in the first year of 'Reihe O' in 2010 the number of more than 700 publications was not reached until 2016. That the number of theses or dissertations listed in 'Reihe H' is decreasing over the last years since 'Reihe O' was established is also shown in the data above.

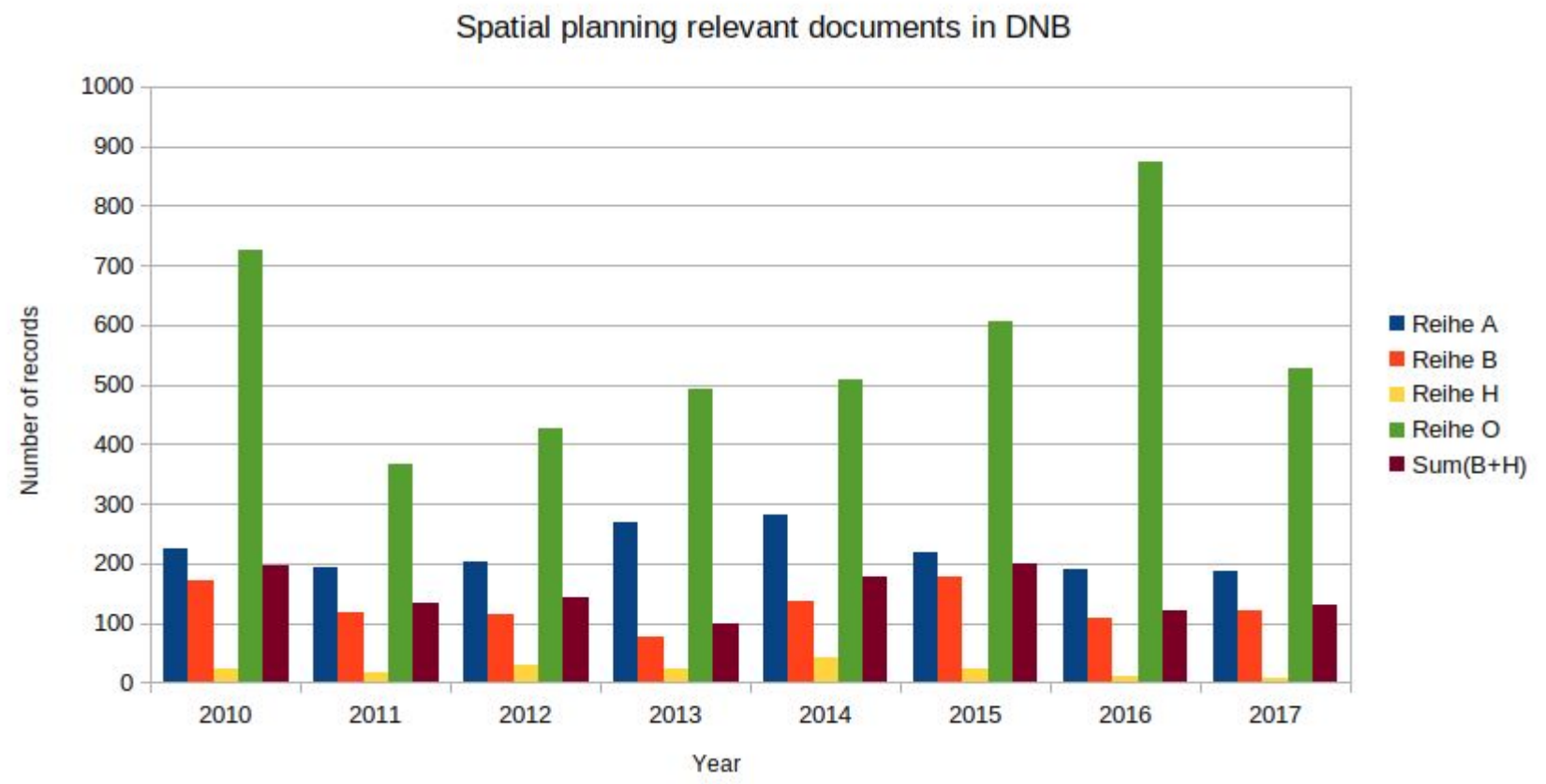

Figure 1: Spatial planning relevant documents in DNB (retrieved by DDC 710)

\section{Spatial planning relevant documents in German national bibliography retrieved by keywords}

The second simple implemented method to retrieve spatial planning relevant documents is to search for different keywords. For this analysis we searched for 'Stadt, Region and Raum ${ }^{30}$, always using wildcards at the end of the keyword to also match different subforms of the keywords like 'Stadtplanung, Stadtentwicklung, Stadtforschung, Stadtgeschichte,...'

\footnotetext{
${ }^{30}$ city, region and space
} 


\begin{tabular}{|c|c|c|c|c|c|c|c|c|c|}
\hline & 2010 & 2011 & 2012 & 2013 & 2014 & 2015 & 2016 & 2017 & Aver. \\
\hline Reihe A & 4210 & 4110 & 3873 & 3434 & 3645 & 3364 & 2951 & 2730 & 3540 \\
\hline Reihe B & 358 & 305 & 251 & 208 & 197 & 204 & 145 & 412 & 260 \\
\hline Reihe H & 382 & 367 & 313 & 322 & 381 & 334 & 311 & 278 & 336 \\
\hline Reihe 0 & 379 & 635 & 956 & 901 & 1458 & 2200 & 2297 & 1938 & 1346 \\
\hline Sum(B+H) & 740 & 672 & 564 & 530 & 578 & 538 & 456 & 690 & 596 \\
\hline Rel. $(\mathrm{B}+\mathrm{H}) / \mathrm{A}$ & 0,18 & 0,16 & 0,15 & 0,15 & 0,16 & 0,16 & 0,15 & 0,25 & 0,17 \\
\hline
\end{tabular}

Tab. 2: Number of Records in German national bibliography retrieved for keyword search.

The numbers in Tab. 2 show that we retrieved a greater number of records than by searching after the classification number. Nonetheless the number of online publications is lower than in the DDC search. Maybe this circumstance is caused by a different way of subject classification. The number of records cataloged in 'Reihe A' is more than 15-times higher than in the first search, although the research excludes all documents described as fictional literature.

\section{Occurrence of grey literature in spatial planning measured in the national bibliography}

The assumed occurrence of grey literature in spatial planning could be measured simply through the number of records in the national bibliography. Table 1 shows the ratio between classical published documents ('Reihe A') and grey literature in the last row.

The average ratio between 2010 and 2017 for documents retrieved via DDC 710 is 1:0.69. For documents retrieved via keywords the ratio is only $1: 0.17$, but the keyword search 
matches a lot of documents handling subjects related to the terms of city, regions or space but without any specific belonging to spatial sciences, like historical studies or guides.

To get an idea what this number says about the importance of grey literature for a specific field we have to compare the numbers with other disciplines. The following Table 3 shows the number of records retrieved by a search for DDC 300 (Social Sciences). The measured average ratio between grey and classical published documents is $1: 0.42$, that means about $30 \%$ less than seen in the spatial sciences. The ratio by comparing spatial science with engineering science in general (DDC 620) is 1:0.85, quite higher and even more stable than in the spatial sciences. Hypothetically the great importance of grey literature is a phenomenon for technical disciplines.

\begin{tabular}{|c|c|c|c|c|c|c|c|c|c|}
\hline & 2010 & 2011 & 2012 & 2013 & 2014 & 2015 & 2016 & 2017 & Aver. \\
\hline Reihe A & 3015 & 2585 & 2404 & 2662 & 2469 & 2260 & 2105 & 2041 & 2443 \\
\hline Reihe B & 776 & 668 & 585 & 550 & 621 & 655 & 450 & 698 & 625 \\
\hline Reihe H & 488 & 385 & 341 & 484 & 474 & 356 & 306 & 343 & 397 \\
\hline $\operatorname{Sum}(B+H)$ & 1264 & 1053 & 926 & 1034 & 1095 & 1011 & 756 & 1041 & 1023 \\
\hline $\begin{array}{l}\text { Rel. } \\
(\mathrm{B}+\mathrm{H}) / \mathrm{A}\end{array}$ & 0,42 & 0,41 & 0,39 & 0,39 & 0,44 & 0,45 & 0,36 & 0,51 & 0,42 \\
\hline
\end{tabular}

Tab. 3 Number of Records in DNB for DDC 300 (Social Science)

\begin{tabular}{|l|r|r|r|r|r|r|r|r|r|}
\hline & $\mathbf{2 0 1 0}$ & $\mathbf{2 0 1 1}$ & $\mathbf{2 0 1 2}$ & $\mathbf{2 0 1 3}$ & $\mathbf{2 0 1 4}$ & $\mathbf{2 0 1 5}$ & $\mathbf{2 0 1 6}$ & $\mathbf{2 0 1 7}$ & Aver. \\
\hline Reihe A & 3121 & 1993 & 1751 & 1922 & 1896 & 1678 & 1564 & 1611 & 1942 \\
\hline Reihe B & 1285 & 670 & 618 & 545 & 681 & 647 & 493 & 704 & 705 \\
\hline
\end{tabular}




\begin{tabular}{|l|r|r|r|r|r|r|r|r|r|}
\hline Reihe H & 1466 & 921 & 775 & 860 & 1087 & 847 & 695 & 944 & 949 \\
\hline Reihe O & 5137 & 3234 & 7979 & 7794 & 6441 & 7537 & 8641 & 7676 & 6805 \\
\hline Sum(B+H) & 2751 & 1591 & 1393 & 1405 & 1768 & 1494 & 1188 & 1648 & 1655 \\
\hline Rel. \% & 0,88 & 0,80 & 0,80 & 0,73 & 0,93 & 0,89 & 0,76 & 1,02 & 0,85 \\
(B+H)/A & & & & & & & & & \\
\hline
\end{tabular}

Tab. 4: Number of Records in DNB for DDC 620 (Engineering science) 


\section{Conclusion}

National bibliographies aim for a wide range of functions and objectives in the bibliographic universe. The catalog of a national library itself is quite similar to a national bibliography, and in most cases library catalog and bibliography go hand in hand and depend on each other, but in a certain way the catalog is the greatest opponent of a national bibliography. This is at best ${ }^{31}$ shown in the presentation and usage of national bibliographies in Austria, where e.g. the former part 'Reihe B' for theses and dissertations and 'Reihe C' for Austriaca were abandoned due to the circumstance that these documents are searchable in the libraries discovery system. Catalogers lost the focus and attention regarding the differences between the two bibliographic instances or the several requirements in information retrieval.

The national bibliography should be more than a static list of bibliographic entries in a chronological order, although the timestamp of cataloging a specific record to the national libraries catalog or bibliography is one of the most important metadata field in this context. The timestamp given through a national bibliography is something totally different than other date/time information in a bibliographic record. he date of cataloging itself gives no information about the novelty of the cataloged publication, also the publication date of the document itself is often differing from the - let's call it - release date of the document. The chronological information from a national bibliography means that a specific record represents indeed a new publication. This information is the central advantage for libraries usage of national bibliographies, especially to curate their own inventories. For end-users like researchers the time information seems not to be the most important fact in such a bibliography, except it is necessary to get an ongoing overview about new publications on

31 https://www.onb.ac.at/digitale-bibliothek-kataloge/oesterreichische-bibliografie/ (accessed January 9, 2014). 
a specific research field or topic. In such use cases it is obligated to have in the discovery tools the appropriate facets or filters to reduce a result list. On the one hand the publication date is a well-known fact in literature research, on the other hand for getting a current overview about the literature a date, which examines that something is new to the library, could be very useful. In this case a national bibliography and its timestamp plays an important and useful role.

Spatial sciences have their own special requirements in information research, some of this could be served well through a national or regional bibliography:

In spatial planning, as it is shown in this article, grey literature has an important role. National bibliographies like the German national bibliography which categorized the publications in their publication form, bring the necessary potential for making information search specified on this category.

Spatial Planning both in research and practice is always close to public authorities. Publications made through these institutions could potentially be an interesting objective to develop new methods of getting metadata or even full-text access to documents over national bibliographies.

National libraries are often responsible for supporting and curating local authority files. Geographical authority files are necessary for a high-quality cataloging of publications with regional coverage.

To get information about new publications, researches have their own ways to get informed, like Social Media, peer groups, mailing lists and so on. A national bibliography could be a worthwhile additional channel. 
To increase the number of relevant spatial planning literature covered through national bibliographies and also its usage by the planning community is not only a task for the national libraries but also for the scientific community itself. It will be a continuous process to encourage both parts to deliver documents as well as to extend the bibliographic infrastructure.

(National) Libraries shall provide discovery tools with geographic functionality, e.g. maps for visualization of items or maps to query the geographic authority file through coordinates.

The spatial planning community has a broad knowledge about geographic information system (GIS), e.g. they could deliver simple or automatically detailed information about a spatial coverage of a specific document. They could also deliver or link GIS data to existing geographically authority file data.

Curating national bibliographies is often based on legal obligations, which doesn't seem to be effective in every way. Spatial planning relevant literature is often produced or released in cooperation with public institutions. To increase the publicity and show the usefulness of national bibliographies, the libraries could start a cooperation with public institutions to deliver spatial relevant literature with all detailed (geographic) information.

If the spatial community got knowledge about new features for research relevant literature based on a national or regional bibliography it would be motivating for other institutions or persons to start delivering their own documents. 
Due to the fact that most of the documents are published only in a digital way, libraries are obligated to build easy-to-use interfaces for uploading, delivering or linking new publications.

If national bibliographies shall be used by a wide range of different users, and not only by librarians, the functionality of the bibliographies has to be improved permanently due to consideration of the requirements from the specific user-groups. A lot of fields of activities for national libraries, like support of authority files, implementation of standardized web-based protocols for data exchange, developing technical methods to get actively notified of national relevant new publications totally independent from the traditional fulfillment of a legal deposit are all relevant to build a modern, stable and user-friendly national bibliography. 


\section{References}

Balzardi. “Das Projekt E-Helvetica Der Schweizerischen Nationalbibliothek”, 2006. https://www.nb.admin.ch/dam/snl/de/dokumente/e-helvetica/publikationen/balzardi elena_dasprojekte-helveticaderschweizerischennationalbi.pdf.download.pdf/balzard i_elena_dasprojekte-helveticaderschweizerischennationalbi.pdf.

Beinert, Tobias, Ulrich Hagenah, and Anna Kugler. "Es war einmal eine Website... Kooperative Webarchivierung in der Praxis". o-bib. Das offene Bibliotheksjournal / herausgegeben vom VDB, Bd. 1, Nr. 1 (2014), 19 December 2014. doi:10.5282/o-bib/2014h1s291-304.

Bell, Barbara L. An Annotated Guide to Current National Bibliographies. 2nd completely rev. ed. UBCIM Publications, new ser., v. 18. München: K.G. Saur, 1998.

Brewster, Kahle. "Preserving the Internet". Scientific American 276, no. 3 (1997): 82-83. Buckland, Michael K. 'Information as Thing'. Journal of the American Society of Information Science 42, no. 5 (June 1991): 351-60.

Danielzyk, Rainer. "Informelle Planung". In Handwörterbuch Der Raumordnung, 465-69. Hannover: Verlag der ARL, 2005.

Deutsche Nationalbibliografie, Reihe O “Online-Publikationen”, 2016. http://www.dnb.de/DE/Service/DigitaleDienste/DNBBibliografie/reiheO.html.

Dimitrovska Andrews, Kaliopa. "Mastering the City: Formal and Informal Planning Tools". Urbani Izziv 9, no. 2 (1998): 111-16.

Directive 2003/98/EC of the European Parliament and of the Council of 17 November 2003 on the re-use of public sector information, EUR-Lex - 32003L0098 - EN § (n.d.). https://eur-lex.europa.eu/legal-content/EN/ALL/?uri=CELEX:32003L0098.

Erlinger, Christian, and Uroš Miloradović. "Vorhabensstudie für ein Fachrepositorium Raumplanung an der TU Wien", 2016. http://resolver.obvsg.at/urn:nbn:at:at-ubtuw:3-2065.

Hansen, Randi Diget. "History and Background". In Žumer, Maja (Ed.). National Bibliographies in the Digital Age: Guidance and New Directions, 2008. http://archive.ifla.org/VII/s12/guidelines-national-bibliographies-electronic-age.pdf.

Hayer, Jürgen. "Überörtliches Planungsinformationssystem Für Österreich”. TU Wien, 2012.

Marsolek, Wanda R, Kristen Cooper, Shannon L. Farrell, and Julia A. Kelly. "The Types, Frequencies, and Findability of Disciplinary Grey Literature within Prominent Subject Databases and Academic Institutional Repositories". Journal of Librarianship and Scholarly Communication 6, no. 1 (30 April 2018). doi:10.7710/2162-3309.2200.

Runkel, Peter. "Fachplanungen". In Handwörterbuch Der Raumordnung, 281-89. Hannover: Verlag der ARL, 2005.

Schöpfel, Joachim. "Towards a Prague Definition of Grey Literature: Transparency in Grey Literature." In Grey Tech Approaches to High Tech Issues, 11-26. Prague, 2010. https://archivesic.ccsd.cnrs.fr/sic_00581570/.

Schöpfel, Joachim, and Dominic J. Farace. "Grey Literature". In Encyclopedia of Library and Information Sciences, 2029-39, 2009. 10.1081/E-ELIS3-120043732.

Van Assche, Kristof, Raoul Beunen, Martijn Duineveld, and Harro de Jong. "Co-Evolutions of Planning and Design: Risks and Benefits of Design Perspectives in Planning Systems". Planning Theory 12, no. 2 (May 2013): 177-98. doi:10.1177/1473095212456771. 
Wiggins, Beacher. "Selection Principles". In Žumer, Maja (Ed.). National Bibliographies in the Digital Age : Guidance and New Directions, 2008. http://archive.ifla.org/VII/s12/guidelines-national-bibliographies-electronic-age.pdf. Žumer, Maja. National Bibliographies in the Digital Age : Guidance and New Directions. Final Draft., 2008.

http://archive.ifla.org/VII/s12/guidelines-national-bibliographies-electronic-age.pdf. 